\title{
Combining Preconcentration Methods for the Determination of Lead and Nickel in Ambient Air by FAAS
}

\author{
Mehmet Yaman* and Ensar Erel \\ Firat University, Sciences Faculty, Department of Chemistry \\ Elazig-Turkey
}

\section{INTRODUCTION}

Due to the rapid industrialization, urbanization, and increased use of automobiles, environmental contamination has increased gradually over the past 25 years (1-3). Among environmental pollutants, metals enter the human body mainly through inhalation and ingestion (4-6). A number of serious health problems can develop as a result of excessive uptake of heavy metals (7-10). Because metals cannot be degraded or destroyed, the assessment of health risks due to metals via ambient air and dietary intake is of great importance. Toxic metals in ambient air can originate from anthropogenic sources such as industrial processes, combustion of fossil fuel, vehicle exhaust, polluted soil, and incinerators. To evaluate and reduce the health and environmental effects of toxic metals in inhaled ambient air and food matrices, it is vitally important to know their chemical compositions and the way they vary in time and space. Therefore, there are continuing efforts to determine particularly toxic metals, including $\mathrm{Pb}$ and $\mathrm{Ni}$, in air phases and food samples (1113). In particular, the determination of trace metals in ambient air samples is an issue of special interest because the absorption rates of metals by inhalation are significantly higher (up to 50-60\%) than by ingestion (between 3-10\%) (14). The accumulation of $\mathrm{Pb}$ and $\mathrm{Ni}$ in the human body can have middle to long-term health risks and can

Email: myaman@firat.edu.tr

Tel: 904242370000

Fax: 904242330062

\begin{abstract}
The main routes of human exposure to toxic trace metals for non-occupationally exposed individuals are inhalation and ingestion through diet. Because the absorption rates of metals by inhalation are significantly higher (up to $50-60 \%$ ) than those by ingestion (between 3-10\%), the determination of trace metals in ambient air samples is of special interest. In this study, three preconcentration methods are combined for the determination of $\mathrm{Pb}$ and $\mathrm{Ni}$ in ambient air by FAAS. For this purpose, the PAR-loaded XAD-7, thiouresulphonamid polymeric resin, and cupferron-activated carbon systems that were optimized in the past were used sequentially, and the seasonal distributions of $\mathrm{Pb}$ and $\mathrm{Ni}$ in ambient air of Elazig City, Turkey, were determined. The obtained $\mathrm{Pb}$ and Ni concentrations are highly variable depending on the season and were found to be in the range of $18-61 \mathrm{ng} \mathrm{m}^{-3}$ and $10.5-47 \mathrm{ng} \mathrm{m}^{-3}$, respectively.
\end{abstract}

adversely affect the physiological functions. It is known that $\mathrm{Pb}$ is toxic to the brain, kidneys, and the reproductive system and can also impair intellectual functioning and fertility, cause miscarriage and hypertension (15-16). In addition, $\mathrm{Pb}$ exposure in school-aged children can significantly reduce their IQ and has been associated with aggressive behavior, delinquency, and attention deficit disorders (17)
The International Agency for Research on Cancer (IARC) has classified inorganic $\mathrm{Pb}$ compounds as "probably carcinogenic to humans" (Group 2A), while $\mathrm{Pb}$ as "possibly carcinogenic to humans" (Group 2B) (18). Due to its malleability, low melting point, and ability to form compounds, $\mathrm{Pb}$ has been used in hundreds of products such as pipes, solder, brass fixtures, crystals, paint, cable, ceramics, and batteries. As a result, populations in at least 100 countries are still exposed to air pollution due to lead in spite of banning the use of lead in gasoline (19). It is remarkable that aviation emissions are included in the "off-highway" emissions category and comprised roughly $50 \%$ of total $\mathrm{Pb}$ emissions for 2008 . However, no studies are available in the literature to characterize the ambient air $\mathrm{Pb}$ concentrations or size distributions of $\mathrm{Pb}$ concentrations in the immediate vicinity of airports (20).

In 1996, the World Health Organization classified $\mathrm{Ni}$ as a trace element that is "probably" essential, given its role in Ni-containing enzymes found in plants and microorganisms (21). However, evidence that Ni has similar functions in humans is not currently available. In contrast, Ni compounds can display a tumor-promoting capability via a number of mechanisms including inhibition of intercellular communication, immortalization of fibroblasts and epithelial cells, the induction of DNA deletions and aberrations, production of DNA-protein cross-links, oxidative damage, inhibition of nucleotide excision repair, and an increase in DNA methylation lead- 
ing to inactivation of gene expression (22). Based on the evaluation of epidemiological studies, the International Agency for Research on Cancer (IARC) concluded in 1990 that "There is sufficient evidence in humans for the carcinogenicity of nickel sulphate and of the combinations of nickel sulphides and oxides encountered in the nickel refining industry." Thus, Ni compounds have been classified as carcinogenic to humans (Group 1) and metallic nickel as possibly carcinogenic to humans (Group 2B) (23).

The Provisional Tolerable Weekly Intake (PTWI) is the maximum amount of a contaminant to which a person can be exposed per week over a lifetime without an unacceptable risk of health effects. The tolerable intake of heavy metals as PTWI is set by the Food and Agriculture Organization/World Health Organization (FAO/WHO) Joint Expert Committee on Food Additives (JECFA). Consequently, the World Health Organization established the PTWI of $\mathrm{Pb}$ at $0.025 \mathrm{mg} \mathrm{kg}^{-1}$ body weight for all human groups, which is equivalent to $250 \mu \mathrm{g} / \mathrm{day}$ for an adult human weighing $70 \mathrm{~kg}$ (24). The JECFA has established a PTWI of $35 \mu \mathrm{g} / \mathrm{kg} /$ week for $\mathrm{Ni}$, which is equivalent to $350 \mu \mathrm{g} /$ day for an adult human weighing $70 \mathrm{~kg}$ (25).

In spite of all these facts, there are few studies available on $\mathrm{Pb}$ and $\mathrm{Ni}$ determination in air samples in comparison to food matrices. This is probably due to the excessively lower concentrations of those metals in an aerial matrix and their determination would require high sensitivity analytical methods such as electrothermal atomic absorption spectrometry (ETAAS), inductively coupled plasma optical emission spectrometry (ICP-OES), or inductively coupled plasma mass spectrometry (ICP-MS). For this purpose, the use of online and/or offline preconcentration methods is suggested such as STAT-FAAS (2627), liquid-liquid extraction, adsorption, and solid phase extraction for the analysis of plant parts such as leaves and shoots for biomonitoring (28-34). Nowadays, long-term monitoring programs are recognized as powerful tools for local, regional, and global studies of atmospheric long-range metals transport processes (35-36).

In this study, $\mathrm{Pb}$ and $\mathrm{Ni}$ concentrations in ambient air from Elazig City, Turkey, were determined. For this purpose, ambient air was collected from air blowers within a period of one hour. The air volume was passed online to three adsorption solutions (PAR-loaded XAD-7, thiouresulphonamid polymeric resin, and cupferron-activated carbon) each in a washing bottle, sequentially placed. After using preconcentration processes of the trace metals described elsewhere (37-39), the clear solutions were analyzed by STAT-FAAS.

\section{EXPERIMENTAL}

\section{Instrumentation}

For the determination of $\mathrm{Pb}$ and Ni, an ATI UNICAM 929 Model flame atomic absorption spectrophotometer (FAAS), equipped with hollow cathode lamps, was used. Table I lists the instrumental operating conditions. The acetylene-air flame in the FAAS, at which the optimal conditions were studied, was used in accordance with the manufacturer's instructions. A slotted tube atom trap (STAT) made from quartz was used to enhance the sensitivity of the FAAS for the $\mathrm{Pb}$ determinations. The applied conditions for the quartz tube were taken from elsewhere (26-27). In the preconcentration experiments, magnetic stirrers and a centrifuge were used. The $\mathrm{pH}$ of the solutions was measured with an EDT GP 353 ATC pH meter (EDT, Dover, Kent, U.K.).

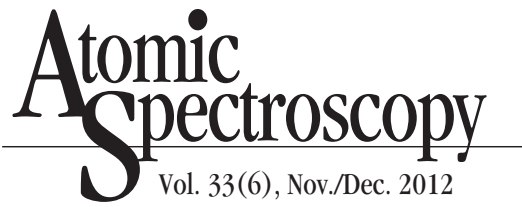

\section{Reagents}

The metal stock solutions (1000 $\mathrm{mg} \mathrm{L}^{-1}$ ) were prepared from their nitrate salts (Merck, Darmstadt, Germany). Concentrated nitric acid (65\%, Merck) and hydrogen peroxide (35\%, Merck) were used for sample digestion after the preconcentration step. All chemicals used were of analytical reagent grade. Doubly distilled water was used for all preparations. All glassware (Pyrex ${ }^{\circledR}$ ) was kept permanently full of $1 \mathrm{~mol} / \mathrm{L}$ nitric acid when not in use.

\section{Air Sampling and Precon- centration}

Representative locations within and surrounding Elazig City (320,000 population in Eastern Turkey) were chosen for this study. The samples for the control site were taken far from the center and from a mountainous area of the city (see Figure 1). Air samples were collected in the period between March and August 2006. Air volumes were collected by using an air blower for one hour at a flow rate of $1.1 \mathrm{~m}^{3} \mathrm{~min}^{-1}$. The air volumes were passed through three adsorption suspensions one in each washing bottle, sequentially placed (Figure 2). There is a separate adsorption solution at a different $\mathrm{pH}$ in each washing bottle, in the order of 1-thiouresulphonamid polymeric resin at $\mathrm{pH} 2.5,2$ - PAR-

\section{TABLE I}

Instrumental Operating Conditions for FAAS

\begin{tabular}{lll}
\hline Parameter & $\mathrm{Pb}$ & $\mathrm{Ni}$ \\
\hline Wavelength $(\mathrm{nm})$ & 217 & 232 \\
HCL current (mA) & 9.5 & 7.5 \\
$\begin{array}{l}\text { Acetylene flow rate } \\
\quad \text { (L/min) }\end{array}$ & 0.6 & 0.5 \\
$\begin{array}{l}\text { Air flow rate } \\
\quad(\mathrm{L} / \mathrm{min})\end{array}$ & 4.0 & 4.0 \\
$\begin{array}{l}\text { Slit width (nm) } \\
\text { Hit }\end{array}$ & 0.5 & 0.2 \\
\hline
\end{tabular}


loaded XAD-7 at $\mathrm{pH}$ 5.5, and 3-cupferron-activated carbon at $\mathrm{pH} 4.75$, previously optimized for preconcentration of $\mathrm{Pb}$ and $\mathrm{Ni}$ as described elsewhere (37-39). Then, the adsorption solutions of $250 \mathrm{~mL}$ were filtered, and the solid phase on the filter paper was dried at $70{ }^{\circ} \mathrm{C}$ for one hour. The dried sample was digested by using a hot mixture of concentrated nitric acid/hydrogen peroxide and occa- sional stirring as described elsewhere (37-39). After removing the acid mixture by evaporation to near the dryness, $3 \mathrm{~mL}$ of $1.5 \mathrm{M}$ nitric acid was added to the residue, stirred, and centrifuged. The obtained clear solution was analyzed by STAT-FAAS for $\mathrm{Pb}$ and FAAS for Ni. To obtain calibration graphs at the same conditions, the model metals solutions were also preconcentrated as described elsewhere

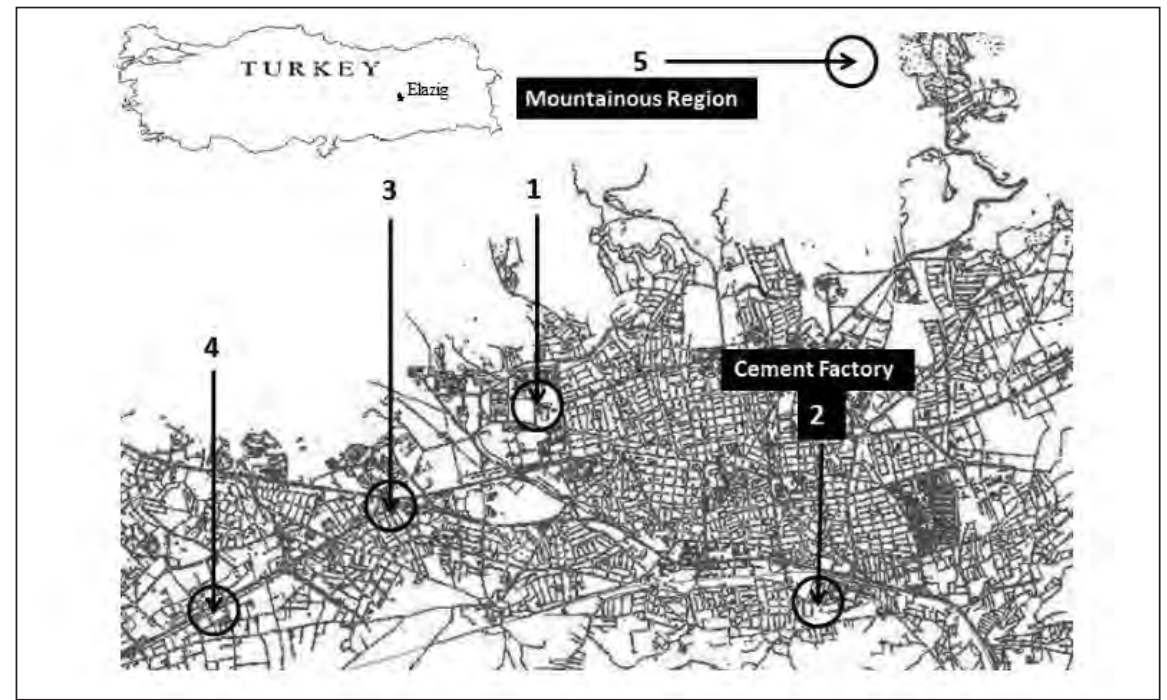

Fig. 1. Map of the study area.

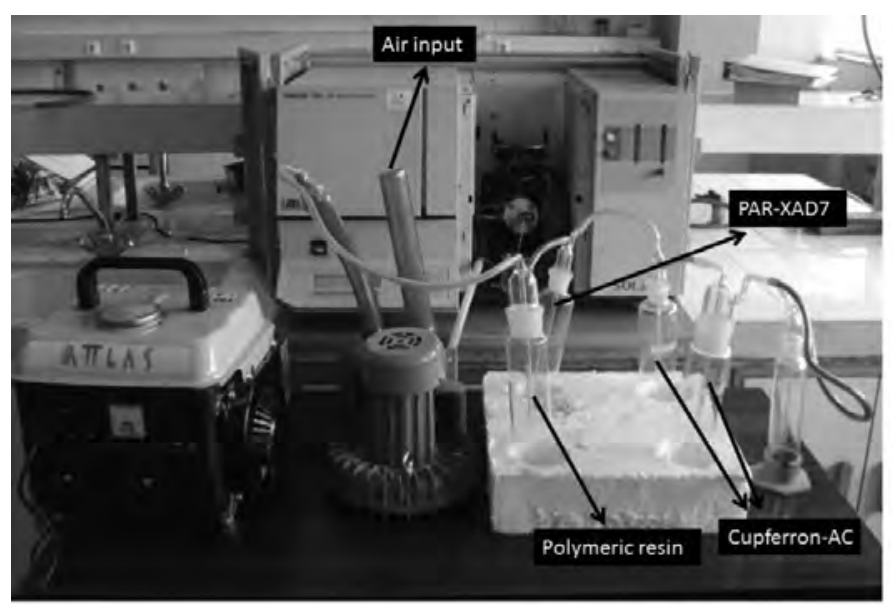

Fig. 2. Illustration of the used experimental system.

(37-39). The results from the calibration graphs were transformed into metal concentrations in ambient air taking into consideration the collected air volume of $66 \mathrm{~m}^{3}$ for one hour.

\section{RESULTS AND DISCUSSION}

Calibration curves were obtained by using the solutions of the studied elements at different concentrations. The obtained graphs were linear in the concentration ranges described below, and the equations of the curves were as follows:

$$
\begin{aligned}
\mathrm{y}= & 0.31 \mathrm{x}-0.07 \\
\mathrm{R}^{2}= & 0.9999 \text { for } \mathrm{Pb} \text { by STAT-FAAS } \\
& (30-400 \mathrm{ng} / \mathrm{mL}) \\
\mathrm{y}= & 86 \mathrm{x}+0.21 \\
\mathrm{R}^{2}= & 0.9995 \text { for } \mathrm{Ni} \text { by FAAS } \\
& (0.1-1.5 \mathrm{mg} / \mathrm{L})
\end{aligned}
$$

In previous studies (37-39), the minimum recoveries of $90 \%$ for $\mathrm{Pb}$ and $\mathrm{Ni}$ from the absorption solutions fortified with these elements were used to establish the metal amounts in the collected air. The blank values were subtracted from the obtained values to eliminate the effects of contamination.

\section{Seasonal Changes in $\mathrm{Pb}$ and $\mathrm{Ni}$ Concentrations of Ambient Air}

Table II presents the average monthly results obtained for $\mathrm{Pb}$ and $\mathrm{Ni}$ concentrations as $\mathrm{ng} \mathrm{m}^{-3}$ in ambient air. Seasonal changes in metal concentrations for Stations 2 and 3 are given in Figures 3-4. The $\mathrm{Pb}$ and $\mathrm{Ni}$ concentrations in ambient air taken from these stations showed a declining trend from the beginning of the spring season to the summer season. In other words, concentrations of $\mathrm{Pb}$ and $\mathrm{Ni}$ peaked in the spring period (rainy season) where the cement dust and flue gases from burning coal near these locations released into the moisture in the air. In the rainless season, the emissions due to dust 
TABLE II

$\mathrm{Pb}$ and $\mathrm{Ni}$ Concentrations in Ambient Air $\left(\mathrm{ng} \mathrm{m}^{-3}, \mathrm{~N}=4\right)$

\begin{tabular}{lcc}
\hline Sampling location/Month & $\mathrm{Pb}$ & $\mathrm{Ni}$ \\
\hline Location 1: Elazig city center/June 2006 & $28 \pm 5$ & $24 \pm 7$ \\
Location 4: August, 2006 & $18 \pm 4$ & $13 \pm 5$ \\
Location 5: Control/ August, 2006 & $19 \pm 4$ & $11 \pm 4$ \\
Location 2: Average of Figure 3 & $27 \pm 6$ & $30 \pm 14$ \\
Location 3: Average of Figure 4 & $39 \pm 18$ & $27 \pm 19$ \\
\hline
\end{tabular}

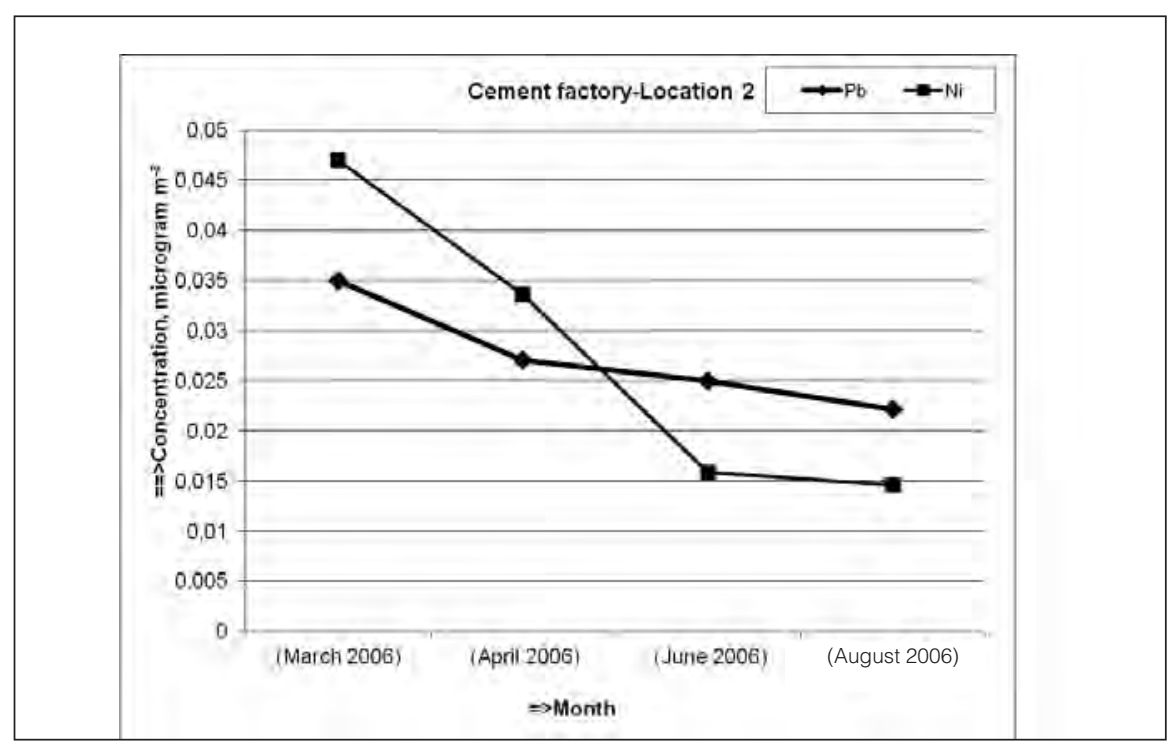

Fig. 3. Seasonal changes in Pb and Ni concentrations in ambient air taken around cement factory, Station 2.

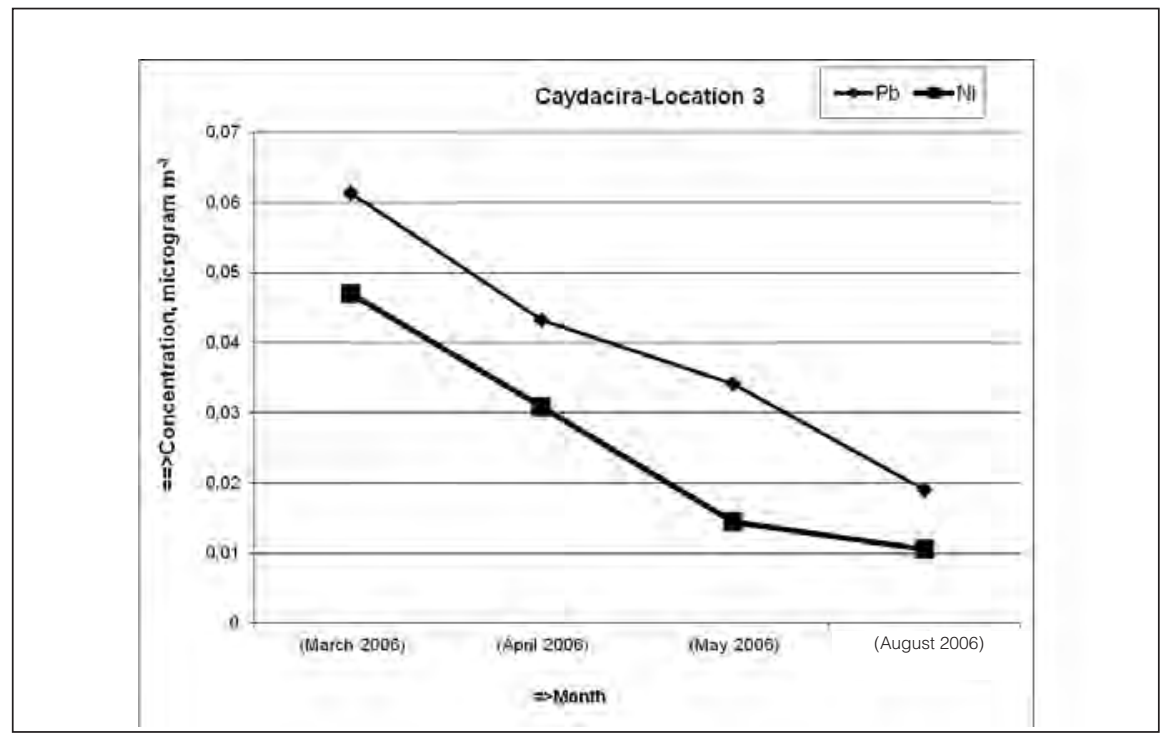

Fig. 4. Seasonal changes in Pb and Ni concentrations in ambient air taken from Station 3. and flue gases can be transported to sites much further away. It is known that combustion of fuels, particularly coal, is the main source of anthropogenic emissions. In the literature, the levels of $\mathrm{Pb}$ and $\mathrm{Ni}$ in cities and urban areas ranged from 24.9 to 111 and 1.0 to $42.6 \mathrm{ng} \mathrm{m}^{-3}$, respectively (40).

In this study, overall $\mathrm{Pb}$ concentrations in ambient air during the study period across the sampling stations ranged from 18 to $61 \mathrm{ng}$ $\mathrm{m}^{-3}$ (Table II and Figures 3-4). The highest value $\left(61 \mathrm{ng} \mathrm{m}^{-3}\right)$ was recorded at Station 3 in March 2006, while the lowest was recorded at Station 4 in August 2006. ANOVA of lead levels showed significant variation among the seasons. WHO established that the annual average lead level in air should not exceed $500 \mathrm{ng} \mathrm{m}^{-3}$ (41). Nickel in the studies samples varied between 10.5 and $47 \mathrm{ng} \mathrm{m}^{-3}$ (Table 1I, Figures 3-4). The highest value $\left(52 \mathrm{ng} \mathrm{m}^{-3}\right)$ was recorded at Station 3 in March 2006 being similar to $\mathrm{Pb}$, while it was the lowest at the same Station 3 in August 2006. ANOVA of Ni levels showed significant variation among the seasons. In 2000, WHO (41) reported that Ni compounds become carcinogenic to humans by inhalation exposure, and assuming a linear dose- response, no safe level for $\mathrm{Ni}$ compounds can be recommended. Briefly, WHO established that the concentrations corresponding to an excess lifetime risk of 1:10,000, $1: 100,000$, and $1: 1,000,000$ are about 250, 25, and $2.5 \mathrm{ng} \mathrm{m}^{-3}$, respectively (41). In another study (42), the highest Ni concentrations in both soil and Cedrus libani leaves taken from Station 3 in the same city were reported and these levels were attributed to the burning of poor-quality coal around this location. Yatin et al. (43) reported that $\mathrm{Ni}, \mathrm{Pb}$, and $\mathrm{Zn}$ concentrations in fine fractions of air particles decreased between 1.0 to 4.0 times from winter to the summer season. 
In our study, similar decreases were found for the $\mathrm{Pb}$ and $\mathrm{Ni}$ concentrations in ambient air from winter to the summer season. Var et al. (4) also reported similar variations in 16 Japanese cities in relation to the yearly seasons.

\section{CONCLUSION}

Although the ban of tetraethyl $\mathrm{Pb}$ in gasoline significantly reduced the airborne $\mathrm{Pb}$ concentrations, monitoring the concentration of $\mathrm{Pb}$ in ambient air is still of high importance because of its common use in our life. The same importance is current for $\mathrm{Ni}$ in ambient air because its compounds are carcinogenic and there is no safe level for its compounds assuming a linear dose-response. $\mathrm{Pb}$ and Ni concentrations in the studied samples are highly variable depending on the season and were found to be in the range of $18-61 \mathrm{ng} \mathrm{m}^{-3}$ and $10.5-60 \mathrm{ng} \mathrm{m}^{-3}$, respectively. The $\mathrm{Pb}$ and $\mathrm{Ni}$ concentrations in ambient air from the winter to summer season decreased between 3.0 and 4.5 times, respectively. While the observed $\mathrm{Pb}$ concentrations in ambient air were lower than the permissible levels (500 $\mathrm{ng} \mathrm{m}^{-3}$ ), $\mathrm{Ni}$ concentrations are at about the $1: 100,000$ lifetime risk. In this study, the combination of previously developed preconcentration methods of PAR-loaded XAD-7, thiouresulphonamid polymeric resin, and cupferron-activated carbon systems were successfully used to determine the $\mathrm{Pb}$ and $\mathrm{Ni}$ concentrations in ambient air.

\section{ACKNOWLEDGMENTS}

This study was supported by the Scientific Investigate Projects of Firat University, Turkey (Project Number: FUBAP-1204).

$\overline{\text { Received August 31, } 2012 .}$

\section{REFERENCES}

1. J. O. Nriagu and J. M. Pacyna, Nature 333(6169), 134 (1988).

2. S. Gucer and M. Yaman, J. Anal. At. Spectrom. 7, 179 (1992).

3. M. Yaman, Chemia Analityczna (Warsaw) 42(1), 79 (1997).

4. F. Var, Y. Narita and S. Tanaka, Atmospheric Environment 34, 2755 (2000).

5. S. Loranger, and J. Zayed, Atmospheric Environment 28(9), 1645 (1994).

6. M. Yaman and N. Cokol, At. Spectrosc. 25(4), 185 (2004).

7. M. Lippmann, K. Ito, J. S. Hwang, P. Maciejczyk and L. C. Cheng, Environ. Health Persp. 114 (11) 1662 (2006).

8. O. A. Ozen, M. Yaman, M. Sarsilmaz, A. Songur and I. Kus, J. Trace Elem. Med. Biol. 16, 119 (2002).

9. S. Kumru, S. Aydin, M. Simsek, K. Sahin, M. Yaman and G. Ay, Biol. Trace Elem. Res. 94(2), 105 (2003).

10. M. Yaman, G. Kaya and M. Simsek, Int. J. Gynec. Cancer 17, 220 (2007).

11. S. Tokalioglu, Food Chemistry 134 , 2504 (2012).

12. M. Tuzen and M. Soylak, Food Chemistry 102(4), 1089 (2007).

13. G. C. Fang, Y. S. Wu, S. H. Huang and J. Y. Rau, Atmospheric Environment 39, 3003 (2005)

14. A. Mulgrew and P. Williams, Biomonitoring of air quality using plants. Air Hygiene Report No 10, Berlin, Germany, WHO CC, 165 pp. (2000).

15. S. J. S. Flora, J. Environ. Biol. 23, 25 (2002).

16. M. Yaman, Curr. Med. Chem. 13, 2513 (2006).

17. J. Schwartz, Environ. Res. 65, 42 (1994).

18. IARC, International Agency for Research on Cancer, Working Group on the Evaluation of Carcinogenic Risks to Humans, Inorganic and Organic Lead Compounds. IARC Monogr. Eval. Carcinog. Risks Hum. 87, 1 (2006).
19. M. Markowitz, American Academy of Pediatrics 21(10), 327 (2000).

20. S. H. Cho, J. R. Bryant, J. Thornburg and J. Portzer, Atmospheric Environment 45, 5005 (2011).

21. WHO, World Health Organization, Trace elements in human nutrition and health. World Health Organization, Geneva, Switzerland (1996).

22. S. A. N. Silvera and T. E. Rohan, Cancer Causes Control 18, 7 (2007).

23. International Agency for Research on Cancer (IARC), Monographs on the evaluation of carcinogenic risks to humans. Chromium, Nickel and Welding. Vol. 49, IARC, Lyon, France (1990).

24. World Health Organization (WHO), Evaluation of certain food additives and contaminants: fortyfirst report of the Joint $\mathrm{FAO} / \mathrm{WHO}$ Expert Committee on Food Additives. Geneva, World Health Organization, (WHO Technical Report Series, No. 837) (1993).

25. EC (European Commission) Working Group of Specialized Experts in the fields of Carcinogenicity and Mutagenicity. Nickel. Summary Record. European Chemicals Bureau, (2004).

26. M. Yaman, Anal. Biochem. 339, 1 (2005).

27. G. Kaya and M. Yaman, Talanta 75, 1127 (2008a).

28. N.M. Karaaslan and M. Yaman, At. Spectrosc. 32(4), 152 (2011).

29. R. Vanderpool, K. Cavender and J. Rice, Atmospheric Environment 45, 5005 (2011).

30. S. Bakirdere and M. Yaman, Environ. Monit. Assess. 136(1-3), 401 (2008).

31. G. Kaya and M. Yaman, Trace Element Electrolyt. 25(3), 156 (2008b).

32. G. Kaya, N. Okumus and M. Yaman, Fresenius Environ. Bull. 19(4), 669 (2010).

33. G. Kaya, C. Ozcan and M. Yaman, Bull. Environ. Contam. Toxicol. 84(2), 191 (2010).

34. M. Yaman, Bull. Environ. Contam Toxicol. 65, 545 (2000). 


\section{A Spectroscopy \\ Vol. 33(6), Nov./Dec. 2012}

35. T. Berg, W. Aas, J. Pacyna, H. T. Uggerud and M. Vadset, Atmospheric Environment 42, 7494 (2008).

36. M. Yaman, Comprehensive Comparison of Trace Metal Concentrations in Inhaled Air Samples, in: Air Pollution - Monitoring, Modelling, Health and Control, Edited by Mukesh Khare, ISBN 978-953-510381-3, Hard cover, 254 pages, Publisher: InTech, Published: March 21, 2012 under CC BY 3.0 License, in subject Environmental Engineering, DOI: 10.5772/2526 (2012).

37. M. Yaman and S. Gucer, Analyst 120, 101 (1995).

38. B.F. Senkal, M. Ince, E. Yavuz and M. Yaman, Talanta 72, 962 (2007).

39. M. Yaman and M. Ince, At. Spectrosc. 27(6), 186 (2006).

40. M. Odabasi, A. Muezzinoglu and A. Bozlaker, Atmospheric Environment 36, 5841 (2002).

41. WHO, World Health Organization, Air quality guidelines for Europe; second edition (WHO regional publications. European series; No. 91) Copenhagen, Denmark, pp. 288 (2000).

42. N. M. Karaaslan and M. Yaman, Instrumentation Science and Technology, Doi:10.1080/10739149.2012.7266 85 , in press.

43. M. Yatin, S. Tuncel, N.K. Aras, I. Olmez, S. Aygun and G. Tuncel, Atmospheric Environment 34, 1305 (2000). 